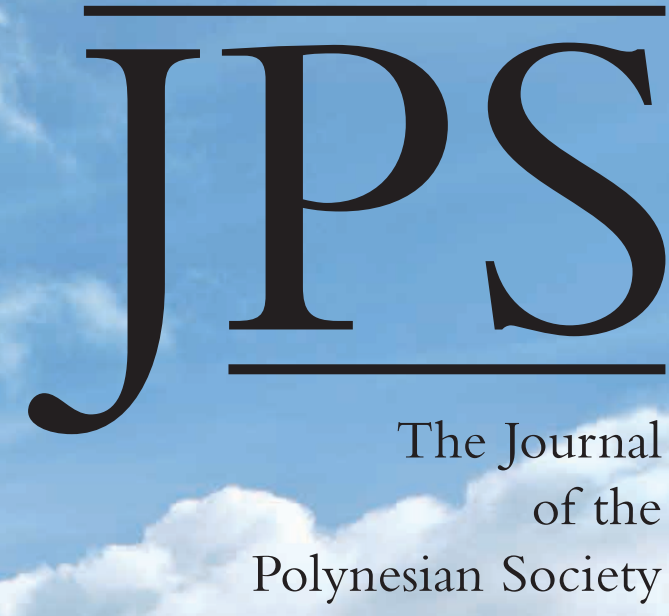

VOLUME 125 No.2 JUNE 2016

Special issue

GRAVE MATTERS IN OCEANIA

THE POLYNESIAN SOCIETY

THE UNIVERSITY OF AUCKLAND

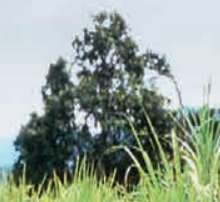

NEW ZEALAND

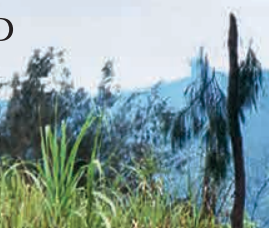

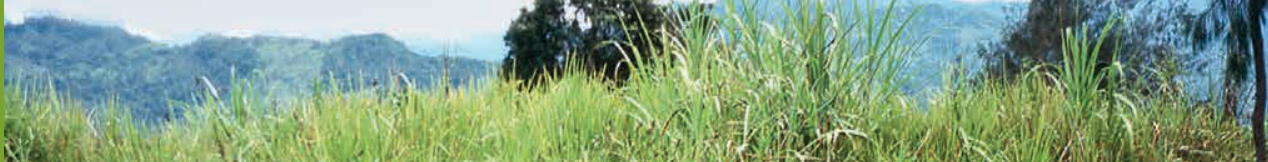

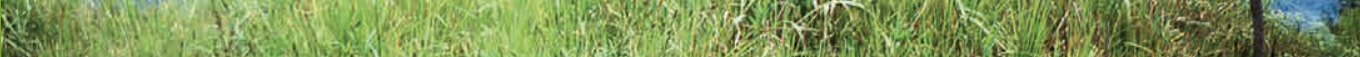

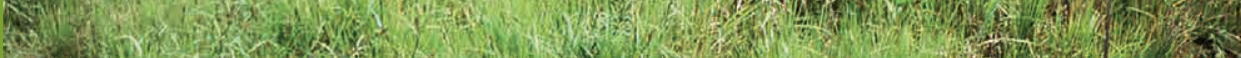

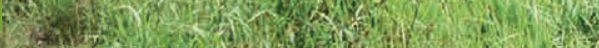




\title{
THE CULTURE OF GRAVES ON ROTUMA
}

\author{
JAN RENSEL and ALAN HOWARD \\ University of Hawai ' $i$ at Mānoa
}

The graves that people prepare for their relatives, as well as the ways they interact with the graves over time, say a great deal about their culture. Among other things, graves themselves reflect attitudes towards death and ancestors, towards hierarchy and social position; the location of graves involves spatial conceptions; grave goods reflect notions of material value; and grave visitations are indicative of the nature of social relationships between various categories of persons. In addition, a variety of emotions - including love, fear, and grief - are embedded and symbolised in the forms, decorations, and care of graves.

In this article we look at graves on Rotuma, a volcanic island in the South Pacific. From a historical perspective, we explore the way social and cultural changes have affected how Rotuman graves are produced and maintained, and the ways in which they, in turn, reflect changes that have taken place in Rotuman society.

By way of background, the island of Rotuma is located approximately $465 \mathrm{~km}$ north of the rest of the islands in Fiji. Although the island has been politically part of Fiji since 1881, Rotuman culture more closely resembles that of the Polynesian islands to the east, most noticably Tonga, Samoa, Futuna and Uvea. Because of their Polynesian appearance and distinctive language, Rotumans constitute a recognisable minority group within Fiji. The authors of this paper have been conducting ethnographic research among Rotumans both on and off the island since 1987 and 1959, respectively. In addition to our own field work, here we draw on the writings of late Rotuman elder and teacher Elizabeth Inia (2001) as well as of visitors to the Island starting in the early 1800 s. ${ }^{1}$

\section{SOME CULTURAL AND SOCIAL-PSYCHOLOGICAL CONSIDERATIONS}

Based on field work conducted on Rotuma in 1959-60, Howard concluded that Rotuman attitudes towards death were less fear-ridden than those of people in Western industrialised societies. He and co-author Robert Scott explained Howard's observations by referring to several sociocultural variables that mitigate the dread associated elsewhere with death, including the following:

Rotumans at the time did not place a high value on mastery of nature and readily accepted death as inevitable rather than obsessively exerting efforts to 
conquer it, whereas in modern Western societies there is a tendency to regard death as an enemy to fight against to the inevitable end.

Westerners place a comparatively high value on being active, even during leisure time, while Rotumans place more value on resting ( $a^{\prime} u$ ' $u a$ ) following necessary labours. Since death represents a state of inactivity, despite religious notions of an afterlife, Rotumans are less prone than Westerners to regard it fearfully.

And, for Westerners, death is associated with social isolation, as a result of cemeteries that are generally removed from the core venues of social life, whereas in Rotuma, burial grounds are generally located within villages, or, in the past, even within family land or houses. (Howard and Scott 1965)

In addition to these cultural and social-psychological considerations, Howard pointed out that people on the island confronted the death of kin and community members far more often than urbanised Westerners, whose families tend to be dispersed and whose involvement in communities is less intimate. As a result of these factors, Howard reported that in 1959-60, at least, his Rotuman consultants tended to describe death as an almost pleasant state, one that frees the individual from the burdens of obligation and work (Howard and Scott 1965: 168).

This is not to say that Rotumans accepted dying passively. Howard and Scott asserted that, in general, there is a distinction between people's attitudes towards death and their attitudes towards dying: "Death is a state or condition into which every organism passes. It refers to the complete cessation of all vital functions of the organism. Dying, on the other hand, is a process, the process of life drawing to a close. Hence, dying usually involves the possibility of avoidance or delay, whereas death is final and inevitable" (1965: 162). Howard and Scott further argued that fear of dying seems to be nearly universal, based on an instinctive motive for self-preservation, whereas attitudes towards death are far more variable and are culturally patterned. We should acknowledge, however, that fear of dying can be overcome when the promise of reward in a conceived afterlife is extremely strong or when the pain of living becomes intolerable.

Like attitudes towards death, the ways in which grief is expressed are also culturally patterned. In earlier times in Rotuma, harming or mutilating oneself were common responses to the death of a child, spouse or close relative, or of a revered chief. According to John Boddam-Whetham, who visited Rotuma around 1870, in addition to the size of a gravestone being associated with the intensity of grief, "the louder their lamentations for the departed, and the more painful the injuries they inflict on themselves, the 
greater the affection they display towards the friends and relatives they have lost" (1876: 266). Among the practices expressing grief were burning spots on the body, cutting off the first joint of the little finger, repeatedly beating one's head, pummelling one's face and eyes, rubbing one's skin off, cutting one's hair off close to the scalp, and subjecting oneself to painful sunburn (Bennett 1831: 478-79, Boddam-Whetham 1876: 267, Lesson 1829: 436-37, Lucatt 1851: 163-64, Macgregor 1932). While most of these practices were discontinued early in the colonial era, wailing in the presence of a corpse continued well into the 20th century.

\section{'Atua: Spirits of the Deceased}

The fear of dying was clearly expressed among Rotumans in their relationships with the spirits of deceased individuals in the form of 'atua, a term that missionary linguist C. Maxwell Churchward defined as "dead person, corpse, ghost". He added that "the last is its commonest meaning, ghosts being very material beings... to the Rotuman mind" (Churchward 1940: 352). Although this definition does not do justice to the use of the concept in Rotuman discourse (see Howard 1996: 122-24), a prominent usage referred to the wandering spirits of dead people who were intent on capturing the souls ('ata) of the living and bringing them to their netherworld abode under the sea ('Oroi-the unseen world). The 'atua of recently deceased loved ones were especially dangerous because of their presumed desire to bring family members with them to the netherworld. 'Atua were also said to compete for the souls of sick people with healers, who relied on incantations and ritual procedures to keep the sick from succumbing.

According to Elizabeth Inia, in a publication concerning Rotuman ceremonies:

The 'Oroians seemed to depend largely on human flesh, so the spirits or 'atua who lived in the 'Oroi around Rotuma went out to steal the souls or lives of human beings and to feast on their bodies. Hungry 'atua returned to the land at night to waylay and steal the souls of friends from their lifetime who were roaming about. A portion of the 'atua - a manifestation — entered the body of the victim.... Animated by its false spirit, the bereft man continued his daily activities, but his character was altered and resembled that of the soul-stealer, when he or she had been alive. Sooner or later the victim wasted away and died. After this, he too became an 'atua, and returned to entrap the souls of yet other people. (Inia 2001: 203-4)

The spirits of recently deceased individuals were said to make their presence known through omens such as the cries of birds, an owl flying by, or other unusual occurrences. They might also appear in dreams. These 
indicated that the spirits were restless, leading relatives to go to the graves to implore them to rest in peace. The spirits of newly deceased individuals were considered to linger in the vicinity for five days, after which a ceremony (teran lima) was held to send the spirit off and lift the death taboos (see Inia 2001: 85-86 for a description of the ceremony).

Once they had accepted their fate and were no longer considered dangerous, the 'atua of close relatives, and especially those of prematurely born children, could be called on for support, according the Mesulama Titifanua, who gave this account in Rotuman to Churchward, who translated it into English:

[Our forefathers] were in the habit of summoning their dead to come to them that they might converse. This they did, at times, [just] because they loved their dead friends so much. They also had great confidence in them when they wanted to know various things, asking their 'atuas to tell them. Especially did they trust in [the 'atuas of] their prematurely born children. They said that the 'atua that had more power to deliver than any other was [that of] a child prematurely born. (Titifanua and Churchward 1995: 124 [editorial insertions in original])

In addition to personal encounters between individuals and 'atua, humans and spirits communicated with each other through mediums (see Parke 2001: 112-33).

The ambivalence expressed towards 'atua suggests that they could be either malevolent or benign, depending on circumstances. When sickness was at issue, or in the presence of a dead body, 'atua were to be feared, but in normal times one could call on the 'atua of family members or close friends for guidance or support. What the foregoing indicates is that, for Rotumans, the worlds of the living and the dead were not distinct; they were both part of a continuous, interactive existence.

What we have described so far were attitudes and practices that prevailed from ancestral times through much of the 20th century. Since then, as Howard observed in an article based on a return to the field in the late 1980s with Rensel, talk about the 'atua has significantly diminished, and behaviour predicated on the actions of 'atua has been much less in evidence. "In 1960 Rotumans were reluctant to go out at night. If out after dark, they walked quickly past cemeteries, and stayed away from localities spirits were said to inhabit. Despite the tropical heat, windows were often closed at night to keep out marauding 'atua" (Howard 1996: 129). Many people at that time gave personal accounts of encounters with 'atua and were eager to tell stories of incidents attributed to their antics. In contrast, during our visits to the island in the 1980s and afterwards, we found that people no longer closed their windows at night, and we were given no warnings or prescriptions 
for avoiding harmful 'atua. "They had, in effect, lost much of their social presence" (Howard 1996: 131).

This change in the place of 'atua in Rotuman social life is relevant to our concerns insofar as it has affected the nature and production of graves and the ways Rotumans have interacted with them over time.

\section{TRADITIONAL BURIAL PRACTICES}

Inia provided a detailed description of traditional procedures associated with burials:

Whenever a person died, the village chief ( $f \bar{a}$ 'es ho 'aga) was informed first so that he could assign people to perform tasks that needed immediate attention: a group of men to dig the grave, another to take down the walls of the house where the corpse was laid; others to cut soapstones from the beach and bring them to the grave; men to provide food from their gardens and bake it for the funeral feast; women to prepare kava for the kava ceremony (because kava had to be chewed by young women); others to cut banana leaves to cover the 'umefe [ceremonial table] for the chiefs in anticipation of the funeral feast....

Before burial, the body was wrapped in fine mats and tied three times - once toward the head, once toward the middle, and once over the legs. If the dead person had been married, the surviving partner and his or her relatives provided the mats for wrapping the body. They had to take the body out through the front door legs first so that his or her eyes faced the direction in which the burial party was headed... the wrapped body was put on a hata, a bier of wood (two long poles with cross pieces), and carried by male relatives to the grave....

The pallbearers' bodies were smeared with a mixture of mena [turmeric: Curcuma longa] and coconut oil, and they wore skirts of fresh ji [ti; Cordyline fruiticosa] leaves. Dressed alike, the village men who accompanied the pallbearers as they walked toward the cemetery (tamura) chanted a ki [which] summoned the strong spirits of old in funerals, in war, in wrestling matches (hula), and whenever extraordinary strength was needed, for example, when large gravestones were carried from the beaches or when dignitaries arriving by boat were carried on a platform. ...

The ki was sung until the wrapped body or coffin was lowered into the grave. The bier had to be dismantled soon after the burial and left at the burial site to rot....

The grave in the olden days was made of four slabs of soapstone erected like a rectangle (fiso 'a) and filled with sand. On top of the grave of a child or a young person, a small stone (lei) was placed as a tombstone; for an older person, and especially on the grave of a chief or a strong man, a large slab of stone (makpurou) was placed on top of the fiso ' $a$. (Inia 2001: 55-56, 61-64, 86; see also Lesson 1829 [II]: 436) 


\section{CEMETERIES AND GRAVES: A HISTORICAL OVERVIEW}

According to Aubrey Parke, an Australian who was a district officer on Rotuma in 1964, cemeteries were "the outstanding features of the... archaeological landscape"; he reported that graves were marked with boulders and large slabs of beach sandstone, which were often carefully shaped, and with "dolmen-like structures with capstone and side stones". People told Parke that it was "important to have a heavy stone on the grave, to press down the spirit of the dead person and prevent it from upsetting living people". Parke expressed amazement that Rotumans could have brought these heavy blocks of volcanic rock over significant distances to the cemeteries. "People explain that the carriers could bear the weight more easily because the spirits of the dead gave them their ne 'ne $i$ (or mana, [a term] used for spiritual power in both Rotuman and Fijian)" (Parke 2001: 36).

Gordon Macgregor, an American anthropologist sponsored by the Bernice P. Bishop Museum in Honolulu, had visited Rotuma in 1932 and, like Parke, was struck by the ubiquity of graves. In his field notes, he wrote that they were "to be found everywhere, under house sites, alongside most of the roadways, in great village cemeteries now preserved by European law, on tops of the little islands along the reefs, and throughout the bush". Whereas Macgregor also noted the presence of unobtrusive or unmarked burials, the most impressive graves consisted of "double stone vaults of great size built up of thick slabs of conglomerate rock or coral cut from the reef. Important graves had top slabs cut from a quarry of basaltic rock in the western end of the Island". One such slab (in the cemetery of the "kings" [sau; see below] atop a hill on the eastern end of the island) measured 17 feet by 7 feet by 1.5 feet (that is, approximately $5 \mathrm{~m}$ by $2 \mathrm{~m}$ by $.5 \mathrm{~m}$ ). Commenting on the question of how Rotumans were able to transport such heavy stones, Macgregor said he was told that having a priest stand on top while uttering prayers made a stone "lighter" for the group carrying it. In addition, Macgregor reported that stones were carried longer distances down the coast on "great crafts" built by Rotumans (Macgregor 1932).

Macgregor elaborated on other aspects of grave construction. Although some graves were marked just by a capstone or monolith, sometimes second vaults were built atop earlier vaults for chiefs and families. Macgregor commented that in some cemeteries real houses had been built over the graves, and he mentioned that in a graveyard in one district, Noa'tau, there was a full-sized European house complete with veranda for the dead to live in. Correspondingly, he was informed by his Rotuman consultants that "stone graves are constructed with the idea that they are houses for the dead". Rotumans called them ri hafu 'stone houses' (Macgregor 1932). 
Regarding the construction of graves in earlier times, Macgregor noted:

The old graves were built in the following fashion: A grave is dug and the four sides lined with stone slabs. The body is laid on the floor which does not have a stone lining, with the head always to the east, so that the body can see the sun come up. A capstone is put on the tops of the walls and the ri hafu is constructed. This is completely covered over with sand and the ends marked with sticks. In five days the pa [enclosure] is built on top. This is set over the ri hafu, the end stones set by the stick markers. This had no cap or table stone. (Macgregor 1932)

Ri hafu were made of sandstone slabs consisting of six pieces in the form of a box, with walls 4 to 5 feet high, with a stone top; some also had a stone floor. Tops could be opened and new members of a family interred, but if a favourite child died, they could "tapu the ri hafu forever", so subsequent deaths in the family would require a new ri hafu (Macgregor 1932).

Describing a cemetery in the district of Oinafa, Macgregor wrote that it was built up of several strata, the lowest being "a large terrace of sand surrounded or edged by a stone wall"; graves in this level were dug and their sides and tops lined by stone slabs. "As these filled up the terrace, later graves were built on top of the first one", with smaller stones used to make the walls instead of the single stone slabs (Macgregor 1932).

The dead were wrapped in mats and buried in sand. The chamber into which bodies were interred was called a $p a$. In former times, according to Macgregor's consultants, it consisted of four slabs that had been filled with sand, but the term had come to be used for various cemetery structures. Later it came to be used for rectangular structures of coral blocks built in the form of an enclosure, then a stone wall without a table stone, and at the time of Macgregor's visit, a small pyramid of limestone or cement built on the sand piled over the grave.

The modern $p a$, Macgregor wrote:

... is a hollow stepped block of cement, built on the sand that is heaped over the grave proper. The old ri hafu has given place to one of cement, made in wooden forms around the spot where the man is to be laid, the morning before the burial. One side of the forms is the sand in which the grave is dug. Perhaps ten inches from this are set up the wooden walls and the cement is poured in between. In a grave I witnessed a piece of iron roof was but put over as a top stone, and the grave covered with sand. The stepped pa which is built in the center of the grave and which is not as large as the "ri hafu" does not have any prototype as far as can be seen. (Macgregor 1932) 
Macgregor noted that the term $p a$ was also used for a stepped foundation (usually with triple steps) built over the spot where a man was killed.

The term sa 'aga was used in reference to a burial pit for all those killed in battle. Such a pit was usually dug not far from the scene of the battle. "The defeated dead were placed on the bottom and the victor's dead were placed on top. The latter were often accorded the honour of being wrapped in mats, but this was not for the loser's" (Macgregor 1932).

A tomb in the cemetery adjacent to the Catholic Church at Sumi is the communal burial place of six "martyrs" who were killed in a war between Catholics and Methodists in 1878. The tomb was spruced up and decorated during the 150th anniversary celebration of the arrival of the first Catholic missionaries in 1846 (see Fig. 1; for an account of the "religious wars", see Howard and Kjellgren 1995).

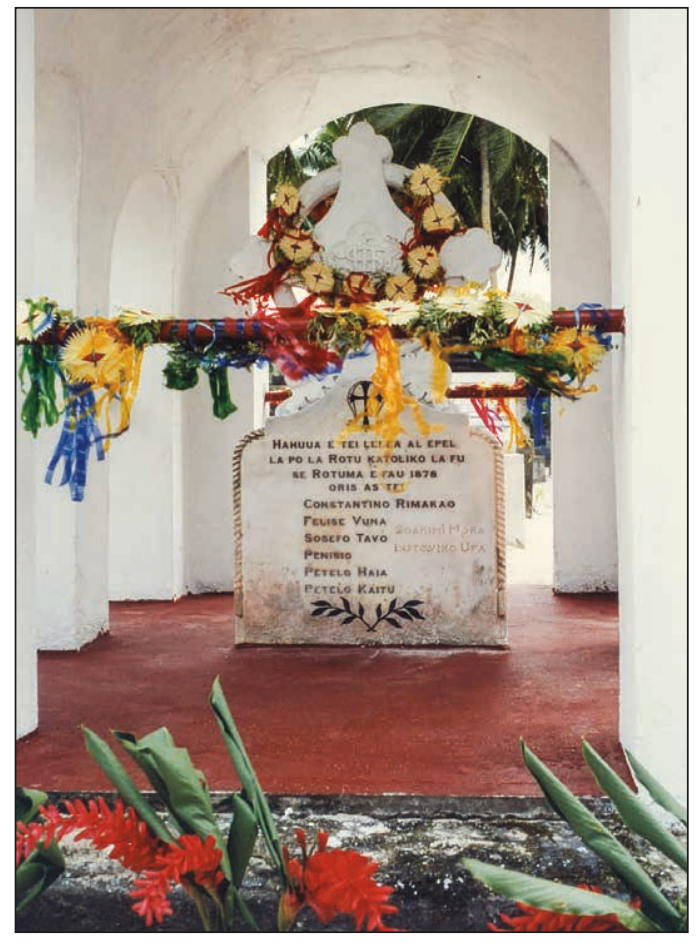

Figure 1. Tombstone of Catholic martyrs from 1878 war. Sumi cemetery, Rotuma. Photo by Alan Howard, June 1996. 
Parke's and Macgregor's descriptions resonate with the accounts of 19 th-century visitors to Rotuma. For example, George Bennett, a physician who visited the island in 1830, wrote: "The ordinary places of burial are attached to the villages, and have no unapt resemblance to European churchyards; they are mounds, built round with stones, and the graves are covered by large coral stones, some laid flat over the graves, and others elevated similar to our tomb stones" (1831: 476). In a footnote, Bennett told of a Rotuman chief who returned from Erromanga with a stone to place on the grave of one of his children; he reported that the chief said that Rotumans like to place stones brought from elsewhere on the graves of family and friends (1831: 476).

Inia made a distinction between the treatment of "nobles" and commoners following death. She stated:

In days gone by, when a noble died, the body was placed in a canoe-shaped wooden trough, called fugaroto, on top of which was hung an apei (fine white mat) as a canopy. The word aroagvaka (canopied canoe) was thus used when referring to the death of a noble. The term ala is the common word for death, and when a commoner died, his or her body was placed on a mat, with a wooden pillow under the head, and the lower part of the body covered with a mat. The upper part of the body was painted with turmeric powder mixed with coconut oil. The bodies of nobles and commoners lay in state for a day and a night, exposed to view, before burial. (Inia 2001: 55)

That rank was associated with the size of graves was attested to by Edward Lucatt, who visited Rotuma in 1841. After the bodies have been buried for "three, six, nine, or twelve months", he wrote:

... a rough, unhewn stone is placed upon the top of them, the size of the stone being regulated by the importance of the party when living. The stone over some of the chiefs cannot weigh less than seven or eight tons.... The placing of these covering stones is the signal for a feast provided by the friends and relations of the deceased; the more massive the block, the greater is the number of hands required to raise it. Thus do they furnish lasting memorials of the rank and wealth once held by those who repose beneath them. (Lucatt 1851: 166)

Two years before Lucatt's visit, the Reverend John Williams visited Rotuma and, after commenting on the crudeness of dwellings in a village he visited, both inside and out, wrote:

The only thing that attracted our attention in this settlement was their buryingplace. Here there was a house rather superior to the others in appearance. It was raised on a bed of sand with stone edging. [His companion] Gray opened two of these trap-doors, when to our surprise we beheld, not only neat clean 
mats spread on the floor, and white cowrie with glittering mother-of-pearl decorating both posts and rafters of the house, but a writing desk, three American chairs varnished yellow, a cup and saucer, tumbler, wine glass, two framed paintings of ships, besides several handkerchiefs, and other articles of European manufacture. On inquiring respecting them, we found that a child belonging to a principal chief had been interred there, and that these things were presented to his manes [spirits of the dead]. (Gutch 1974: 562)

J. Stanley Gardiner, a British naturalist who visited Rotuma in 1896, elaborated on the relevance of rank to the location and size of graves. Whereas graveyards in the bush were scattered everywhere, he wrote, without stones or monuments, in former days chiefs were buried on the highest hills in their districts or on a conspicuous prominence into the sea:

On the tops of many hills and islets off the coast are platforms, built up at the sides, with graves marked out on the top. On the top of Sol Hof, the highest hill in Oinafa, is one such; the summit is a narrow ridge, on which at one end a platform has been built up about 30 feet long by 20 broad. Its walls vary in height up to 8 feet, and are built simply of the loose rough blocks of lava that are found in the vicinity. On the top, areas are marked out by flat stones, about 2 feet square by 3-4 inches thick. Six placed vertically enclose the grave, two at each side and one at each end, and project for about 8 inches above the general level. In the middle across and resting on them is another similar block, the same size. These are formed of a sand rock, which is only found on the beach between tide marks, and which, while it is at first extremely friable, on exposure to the air gets very dense and hard. (Gardiner 1898: 431)

Gardiner noted that practices had changed during the 19th century and that at the time of his visit most burials of district chiefs were in their own villages:

In each district is one such enormous more or less rectangular burial ground, a mound of sand walled in by large rectangular blocks of beach sand rock or unshaped pieces of lava; their construction was apparently gradual, and similar to those on the tops of the hills. Their height varies up to as much as 16 feet, while they may be 30 yards or more square; some are terraced. Many are placed on prominent capes into the sea, and most are visible from it; those at Oinafa and Matusa are especially conspicuous. Their number is enormous, and there are very great variations in size and position, but a height of about 6 feet to start with, unless on some prominent raised point, seemed to me general. From these, the whole island of Rotuma was formerly known to sailors as the island of graves. (Gardiner 1898: 432)

Gardiner also noted that the carvings on some of the newer stones were copied from markings on crockery, and that people were, at the time of his visit, being buried "in the English fashion" (1898: 433). 
An innovation in grave construction was the use of cannons brought by European vessels during the 19 th century. As early as 1839 , missionary John Williams reported finding a cannon under a covering of leaves on the beach and was told that there were several scattered around the island that had been purchased from various ships that had called at Rotuma (Gutch 1974: 562). In 1959, Christopher Legge, Fiji's Commissioner Eastern, reported that he found ten cannons on the island, all in cemeteries (Legge [1960]). A cannon was unearthed by Deputy Commissioner Romilly in 1880 at Sisilo (Fig. 2), the burial ground of the sau (see next section). Romilly reported in his journal that he exhumed the skeleton of a sau who had been buried in 1863, and that "after lifting a stone which it took our whole party to move, two natives dug for about six feet, when we unearthed an iron cannon, which had been put in with the departed Sau, as being his most valuable possession" (Romilly 1893: 103). Legge speculated that in addition to the cannons on the surface "there may be a number buried in the graves of departed Chiefs" (Legge [1960]). Parke (2001:36) hypothesised that the cannons were used as weights to press down the spirits of dead persons, just as heavy stones were used in earlier times, but we think a more likely interpretation is that they were symbols of potency appropriate to persons of chiefly rank.

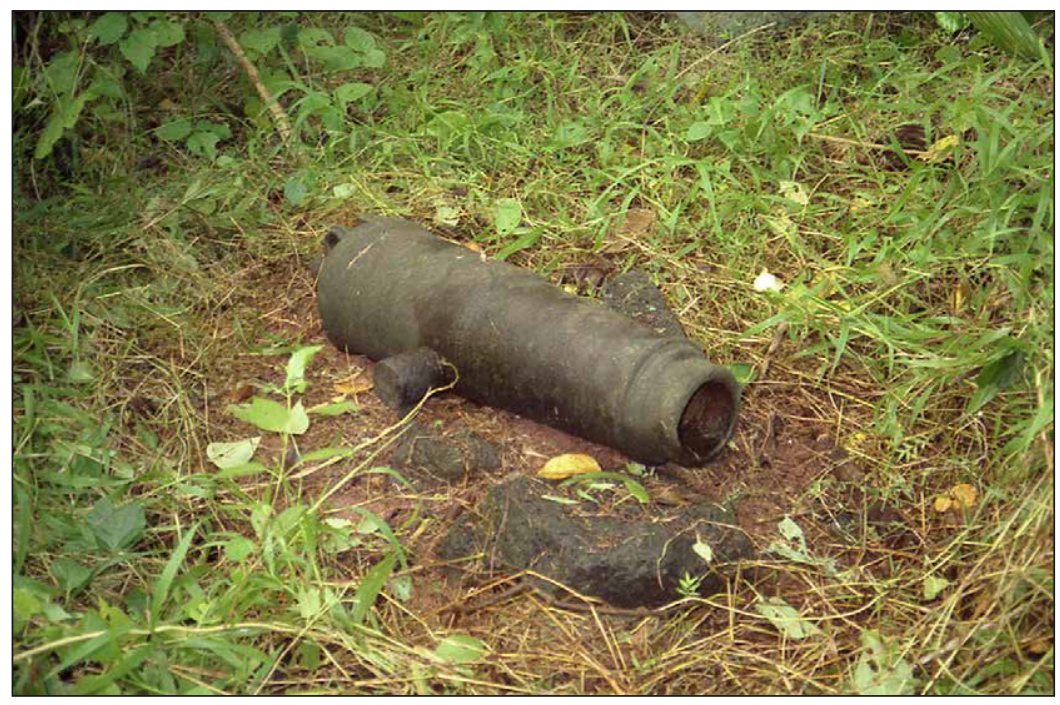

Figure 2. Cannon in Sisilo, the graveyard of the sau 'kings' of Rotuma. Photo by Alan Howard, July 1988. 


\section{GRAVEYARDS OF THE SAU AND MUA}

Of special significance in the pre-Christian era were the graveyards of the sau and mua. At the time of European intrusion in the early 19th century, Rotuma was divided into seven districts (see Fig. 3), each relatively autonomous and headed by a gagaj 'es itu ' $u$ 'district chief'. However, there were also three positions that were pan-Rotuman in scope: the fakpure, sau and mua. The fakpure was referred to primarily in two capacities in the early literature: as convener and presiding officer of the council of district chiefs, and as the person responsible for appointing the sau and ensuring that he was cared for properly. The fakpure was chief of one of the districts, presumably the one who headed an alliance that was victorious in the last war. The sau was an object of veneration and gluttonous indulgence; his basic role was to take part in the ritual cycle, oriented towards ensuring the prosperity of the island. The role of mua received less commentary in the early literature than that of fakpure and sau, but most of what was written refers to the mua's activities in the ritual cycle. A French priest, Fr Joseph Trouillet, wrote in about 1868 that the sau appeared to be an appendage of the fakpure, while the mиa appeared to be more associated with spiritual power. The office of sau (often translated as "king" by early English commentators, despite the fact that he held no secular authority) was rotated among the districts in time frames ranging from six months (one Rotuman ritual cycle) to several years, depending on the prosperity of the island and the willingness of hosting districts to continue the lavish indulgence of food and kava required (for more extensive discussions of these pan-Rotuman offices, see Gardiner 1898: 460-66, Howard 1985, Howard and Rensel 2007: 59-84, Ladefoged 1993). The institution of sauship, and its associated ritual practices, was terminated in 1873 , following the conversion to Christianity of most Rotumans.

\section{Sisilo: The Sau's Graveyard}

The burial ground of the sau was at Sisilo, on the highest hill at the eastern end of the island, in the district of Noa "tau. The eastern or "sunrise" end of the island is associated with chieftainship by Rotumans, the western or "sunset" side with people of the land (Howard 1986), so the placement of the sau's graveyard can be considered the inevitable product of Rotuman cultural logic. Lesson visited the site during his 1824 stay on the island and described it as "scrupulously maintained and surrounded with beautiful island trees which have been planted with care. At the head of each tomb rises an eight foot stone, at the foot, one of four feet and two long stones mark the sides" (Lesson 1829 [II]: 437 [translated from the French by Ella Wiswell]). Gardiner reported that many of the stones at Sisilo were immense - including 

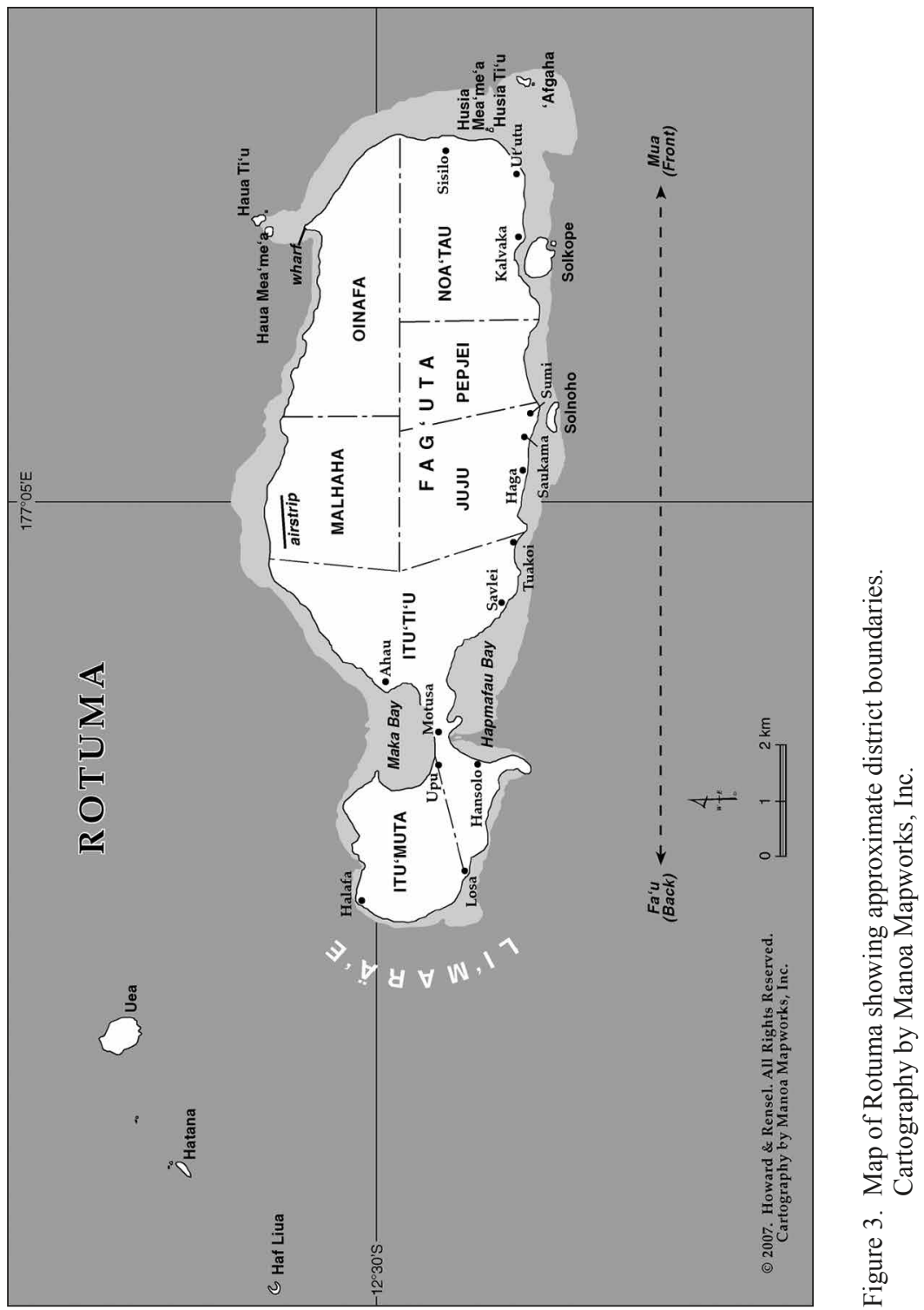
one about 10 feet long, 5 feet wide, and 5-6 inches thick - while another grave was topped by a small cannon. He observed, "The bodies are recumbent and buried about 6 feet deep" (Gardiner 1898: 464).

Parke visited Sisilo in 1964 accompanied by three Rotuman men, including the district chief of Noa'tau and the owners of the land, who maintained the cemetery. He reported:

We saw several sorts of graves. In some cases a circular pile of stones with an empty place in the middle marked the grave. In other cases, the markers were side walls with a capstone... or with an upright stone at the end. Remarkable features included enormous slabs of Ran 'Avi'i stone; the päega ne sau (the throne of the sau), which is a volcanic boulder; the tano ' $a$ (kava bowl), which is a slab of Ran 'Avi'i stone with circular and other hollows; and a large iron cannon....

During our visit, Fakraufon's guide, who was the owner of the cemetery, told us about what happened when a sau died. The body of a sau was taken to Saurotuma, where the people of Saurotuma waited until a pepe fisi (white butterfly) came to lead them to Sisilo. When the butterfly appeared, they picked up the body and followed the butterfly to Sisilo. They buried the body in the part of Sisilo where the butterfly disappeared. The butterfly is the tu 'ura (bird or animal in which the spirit of a dead person appears) of an 'atua from Sisilo. (Parke 2001: 78-79)

\section{Muasolo: The Mua's Graveyard}

The тиа were buried on Muasolo, a small hill near the village of Lopta, in Oinafa District. According to Gardiner, the тиа were buried in a sitting position with a pearlshell breastplate around their neck and a stone axe between their legs. He described the graves as simply covered by a mat but with a "native house" over them. (During periodic feasts thereafter, the house was re-thatched, with the old thatch equally divided among the participants to ensure the possessors a fruitful season.) Gardiner was told that when a former тиа died he had to be buried by the living тиа. After the burial, a tanoa 'bowl' full of kava was poured out to the dead mua. A great quantity of food was then placed in the house and left there. Only the mua could enter the house, so he had to carry all the food in by himself while the old men and women walked in procession around the house, chanting a prayer for a fruitful season (Gardiner 1898: 464-65).

Allardyce was told that if the previous mua had died a natural death the mua who replaced him was required to bury him at Muasolo, and

... to unearth the last mua in order to obtain the stone axe, called 'voirou,' which it was customary to bury with the mua - a different axe, however, 
being buried with each mua. If the stone axe was easily found, the opinion was that the new mua would be a very good one. The axe was then wrapped up, carried home, and taken very great care of. (Allardyce 1885-86: 142)

\section{POST-MISSIONARY AND COLONIAL CHANGES}

Whereas family members were often buried in or close to dwellings prior to European intrusion, the practice was frowned on by missionaries and colonial administrators when they arrived in the latter part of the 19th century. At a meeting of the Rotuma Council of Chiefs in 1884, just three years after Rotuma was ceded to Great Britain, Resident Commissioner William Gordon recorded the following exchange with two of the chiefs:

R.C. "I wish to speak today about the grave-yards in Rotumah. There are many of them quite close to houses in which people are living and in some cases houses are actually built in the graveyard, amongst the graves. I have noticed with the last month one or two newly made graves within two yards from the houses. Now this cannot be healthy. I think it would be much better if you Wesleyans would enclose a space in each District, away from any town, as a burial ground, as the Catholics have already done."

Vasea: "Quite lately, at the town of Ropuri, where there are several houses in a burying ground, there were two persons buried actually inside the houses, the mats being taken up $\&$ the graves dug $\&$ filled in, \& the people continuing to live in the houses all the time. It must be bad."

Horatio: "... according to old custom nearly every family has its own burialground, very often close to their houses...". (Handwritten notes from Minutes from the Rotuma Council of Chiefs, obtained in 1959 from Fiji Archives)

Gordon took the initiative to draft [Rotuma] Regulation No. 1 of 1885 .Regarding Graveyards, which read:

1. It shall not be lawful to bury bodies in ground underneath occupied houses.

2. It shall not be lawful to bury bodies in graveyards on which occupied houses are at present existing.

3. It shall not be lawful to erect any dwelling-houses on graveyards in which bodies may be buried,

4. There shall be a penalty of five pounds for each breach of this Regulation.

Passed by the Rotumah Regulation Board the sixteenth day of October, 1884.

And Macgregor's notes concerning graves include the following entry:

It was quite common in Rotuma to bury the dead in the floor of the house. According to Varomua only a ri hafu was made, with the stone top the 
level of the floor. However, the burial of Chloe Howard in Juju had a large European stone 6' x 4' laid over it and the family used it as a table and bench. Commissioner MacDonald forbade house burials and caused the house of Chloe to be burnt down and the spot left clear. (Macgregor 1932)

The missionaries persuaded people to set aside land for cemeteries where none previously existed, and the Catholic Church at Sumi created a cemetery adjacent to the church (see Fig. 4).

Macgregor described contemporary (as of 1930s) practices in the following notation:

The grave itself is made of four stone slabs cut or taken from the beach, and set up as a chamber just wide enough and long enough to hold the body. Each slab is set on edge to make a long, thin boxlike chamber. Then a fifth stone is laid over the top to close the grave. This then is covered with sand which is flattened on top. Sometimes the sand will be made into a small terrace and then another pile is put on top leaving a flat foundation of the terrace around it. The top pile is smoothed off. This is tended every day, swept and smoothed off. Flowers, garlands, strings of titi [woven strips of pandanus], are brought to decorate the grave. The strings are often suspended over the graves. The family visits the grave every day. Food is left on it at night for the dead. Stories are told here, dances held on the top of the flat tops, food

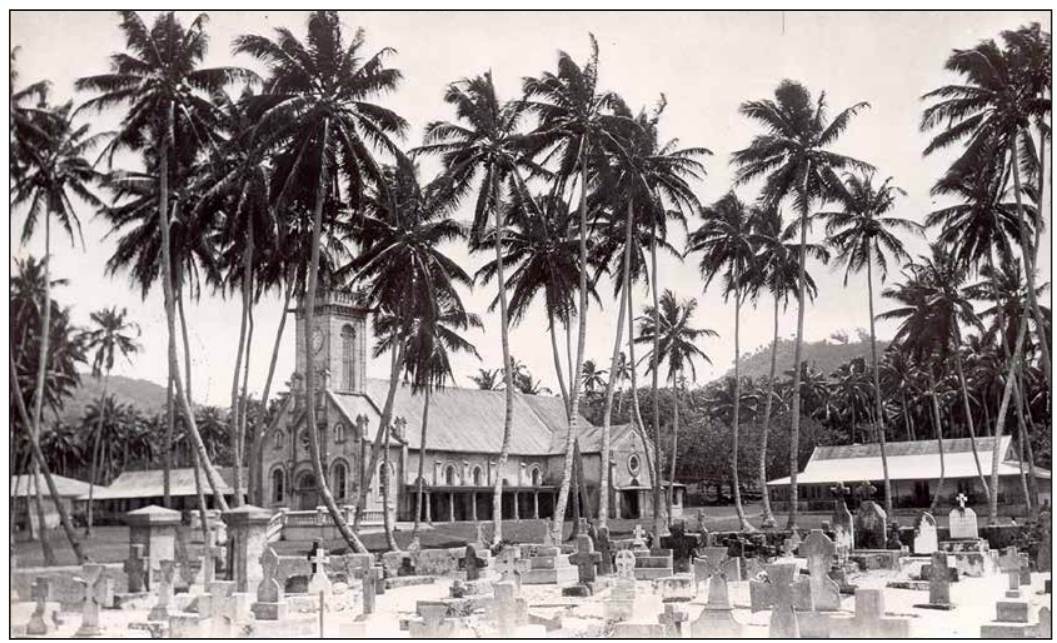

Figure 4. Cemetery in the compound of the Catholic Church at Sumi, Rotuma, circa 1920. Photo courtesy of the Marist Archives, Rome. 
eaten here, and lights and food left on top at night for the dead. Graves are gathering places where the relatives come and sit with the dead.... Perfume is poured over the graves and over the attendants and friends at the funeral. Formerly the Rotumans made native perfume. Bottles of perfume are buried today with the dead. (Macgregor 1932)

The sand that is poured over the grave is significant insofar as it is symbolic of the place it comes from. Ordinarily, when a corpse is interred in its home village, the sand from an adjacent beach insures that the spirit of the deceased will be "at home" in the grave. However, as sometimes happens, a wife or husband has come from another part of the island. When they die they may be returned to their home village for burial, but sometimes their children want them to be buried locally, where they can tend to the grave. In such circumstances, it is customary for some sand to be brought from the person's home village and sprinkled on the grave, insuring the spirit's association with its original home so it will not be restless and cause mischief.

In addition to banning burials within and near homes, the colonial administration instituted a rule that burials should occur on the day that deaths occurred, citing health concerns. And whereas in earlier times grave construction was completed as soon as practicality permitted, it became customary at some point to hold a ceremony setting the headstone (höt 'ak hafu) on approximately the first anniversary of the death. This allows relatives time to have a headstone made (often in Fiji or abroad), for family members off-island to make plans to return for the ceremony, and for such preparations as planting crops and plaiting mats necessary for a proper ceremony. The ceremonial event was described in detail by Inia:

The höt 'ak hafu marked the end of the mourning period. Until this event, the immediate family of the deceased visited the grave regularly, bringing flowers and tefui [garlands], and fresh sand from the beach. Höt'ak hafu were essentially family functions. The family fixed the date, informed close relatives and friends, and bore most of the expenses involved. The villagers helped by donating root-crops, pigs, mats, and money.

In the interim between the teran lima and höt'ak hafu, family members received messages through the dreams and trances of tu' 'ura (spirit mediums), urging them to compose songs about the deceased. Certain individuals on the island were famous for composing songs and could be approached with information about the messages received in dreams or trances. The composer who was commissioned selected a number of people to sing and dance at the höt'ak hafu, and they began to rehearse (taumaka) in preparation for the event. Just prior to the day, a shelter (ri hapa) was built right outside the back of the house, where the singers and dancers would perform.

On the day of the höt'ak hafu a päega (seat of mats) was prepared for the chiefs along the front wall. The päega was in the middle of the row of 
chiefs, occupying the place of honour. The first mats to be put down were the agrua (large floor mats); on top of these went the 'eap ma 'on faua (smaller floor mats); then came the 'eap hapa (sleeping mats); and finally the apei. The immediate family and close relatives of the deceased made all the mats for this päega. The seat was covered with a silky cloth on top of which the tombstone was placed face up for all to see.

A second päega, placed beside the main one, was prepared for the craftsman (majau) who made the $p a$ (concrete platform on which the headstone was to be placed). This päega was made from mats contributed by friends, neighbours, and more distant relatives. It was constructed in the same way as the first päega, with agrua at the bottom and apei on top.

Just before the start of the ceremony, the male who was next of kin to the deceased (such as the eldest son, brother, or grandson) sat on the first päega behind the tombstone. On his lap was a folded apei on which he placed the base of the tombstone so that the lettering faced the people in front of him. He braced the tombstone against his chest. The majau sat on the second päega and the chiefs took their places on either side of these two seats.

Then the mamiag hafu was performed. A girl from the family (a sister, wife, or daughter) came forward with two tefui (one for the stone, one for the person sitting behind it) wrapped in an 'apea leaf, a bottle of scented coconut oil, and a cloth with which to wipe the stone. She knelt down and poured a few drops of oil on top of the stone and with the cloth rubbed the oil over the front surface. As with a mamasa [welcoming ceremony], anointing with oil is a way of symbolically washing away the salt that comes with travelling over the sea. The girl then tied a tefui around the stone; the second tefui she put around the man's neck. She withdrew and a second girl came forward to put a tefui on the majau. (In recent years, after putting a tefui on a person or headstone, the girl sprays it with perfume. This is not really necessary because tefui are made from sweet-smelling flowers that produce a scented atmosphere that remains until the flowers wither.)

The mafua [ceremonial elder], who had been sitting by the back door during these rituals, then announced: "Kalog! Gou täla usia'afua, mamiag hafu te', päegat, agrua saghul, 'eap ma 'on faua ruaghul, 'eap hap limaghul, rer sema siliket, sar het, liuliu het; 'ia', marie', marie', marie'!" (Sirs, I am going to announce, the rinsing of the headstone with oil, päega, 10 agrua, 20 'eap ma 'on faua, 50 'eap hapa, topped by silky material, tefui, oil, thank you, thank you, thank you!)

At this point the man holding the tombstone rose and carried it to the cemetery. A procession of close relatives followed. The tombstone carrier was preceded by the majau who, together with a small group of helpers (who had waited at the gravesite while the ceremonies were taking place in the house), prepared to mount the tombstone. The majau and his helpers mixed the cement that formed the base for the stone. When the cement was ready, the tefui was removed from the tombstone and put aside, and the stone handed over to the majau who, with his helpers, put it in place. When they finished mounting the stone, the majau and his men stuck four poles in the ground, one off each 
corner of the grave. The women, many of whom had brought tefui and baskets of white sand, now strung the tefui between the poles and poured the baskets of sand around the grave. The tefui worn by the man carrying the tombstone, the tefui of the majau, and the tefui that had decorated the tombstone were now placed on the grave, and the people returned to the house for the sui putu (ceremony to end the mourning restrictions). (Inia 2001: 87-90)

$$
\text { *** }
$$

In Rotuma, while the graves of high-ranking officials (sau and mua, and possibly district chiefs) were traditionally located on the tops of hills or on offshore islands, away from villages, the graves of most people were integrated into social space occupied by close relatives, reflecting a sense of continuity between the living and dead. We suggest that because graves were, and continue to be, very much a part of the social landscape, along with the value placed on resting, a lack of concern for mastering nature, and a familiarity with death that comes with village life and the proximity of numerous kin, that Rotumans do not fear death to the degree that is characteristic among urbanised Westerners.

Whereas in the past grave construction reflected social hierarchy with the tombs of high-ranking individuals involving elaborate stone structures, this is no longer the case. In part this change is the result of a greatly diminished hierarchy, with the roles of sau and mua eliminated and the authority of district chiefs much reduced (Howard 1966, Howard and Rensel 1997). In part it reflects the policies of missionaries and colonial administrators who favoured European-style cemeteries with headstones as grave markers. While contemporary headstones vary in quality (and hence cost), they are more likely to reflect the wealth of family members than rank.

Although at night cemeteries may still produce a sense of the uncanny or even fear associated with ghosts, during the day they are an integral part of the social sphere of activity in most villages. Children may use them as playgrounds and adults may come to sit by a grave and speak to a deceased relative. Many graves include the bones of ancestors that are dug up when a new body is interred, and it is common for the bones to be handled and regarded with curiosity rather than treated either with reverence or apprehension.

Graves are decorated at the time of burial, but much more elaborately at the höt'ak hafu ceremony when the headstone is placed, approximately a year later, with garlands of flowers, colourful ribbons and cloth, and woven strips of pandanus. Especially during the placing of the headstone, the mood tends to be light-hearted, with much conversation and joking accompanying the work of completing the grave. Afterwards, close relatives and good friends may visit the grave from time to time, bringing fresh flowers and the 
deceased's favourite foods, weeding and keeping the grave well groomed. In many parts of Rotuma, time is set aside for communal projects to maintain local cemeteries in good order.

Nowadays, far more Rotumans live in urban Fiji than in Rotuma and are buried there as well. Cemeteries are generally separated from residential areas, so the situation is quite different from Rotuma. Nevertheless, burials there still often include many components of burials on the home island, with graves decorated in the customary way following a höt 'ak hafu ceremony and visited regularly by loving relatives (see Fig. 5).

For individuals who were born and raised on Rotuma but who died in Fiji, the selection of a burial place can become problematic and occasionally contentious. The choice may be between having one's body returned to Rotuma for burial amidst one's relatives in one's ancestral village, or burial in a cemetery in Fiji where one's children and others can visit the grave on a regular basis. We know of at least one case in which an older woman was brought to Fiji from Rotuma during her final illness and, although she expressed a desire to be buried in her home village in Rotuma, her children decided to have her buried in a nearby cemetery where they could visit and care for her grave.

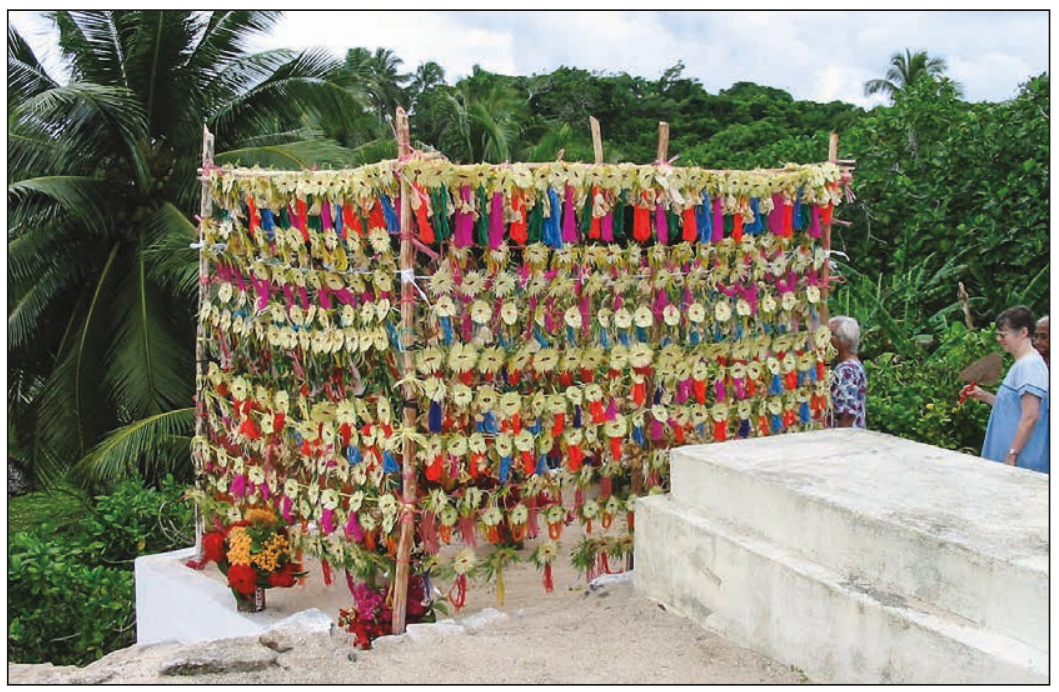

Figure 5. A grave decorated with Rotuman garlands (tefui) in a cemetery near Suva. Photo by Alan Howard, June 2003. 


\section{NOTE}

1. The first written mention of Rotuma resulted from a brief visit in 1791 by Captain Edward Edwards in H.M.S. Pandora, searching for the mutineers of the Bounty. Wesleyan and Roman Catholic missionaries first arrived in 1839 and 1846 , respectively, and by 1871 , most Rotumans had converted to Christianity. The chiefs of Rotuma ceded the island to the British crown in 1881, after which Rotuma was administered as part of the colony of Fiji. Since Fiji's independence in 1970, Rotuma has been part of that country.

\section{REFERENCES}

Allardyce, W. L., 1885-86. Rotooma and the Rotoomans. Proceedings of Queensland Branch of the Geographical Society of Australasia. 1st sets: 130-44.

Bennett, George, 1831. A recent visit to several of the Polynesian islands. United Services Journal 33: 198-202, 473-82.

Boddam-Whetham, John, 1876. Pearls of the Pacific. London: Hurst and Blackett.

Churchward, C. Maxwell, 1940. Rotuman Grammar and Dictionary. Sydney: Australasian Medical Publishing Co.

Gardiner, J. Stanley, 1898. The natives of Rotuma. Journal of the Royal Anthropological Institute 27: 396-435, 457-524.

Gutch, John, 1974. Beyond the Reefs: The Life of John Williams, Missionary. London: Macdonald and Jane's.

Howard, Alan, 1966. The Rotuman district chief: A study in changing patterns of authority. Journal of Pacific History 1: 63-78.

1985. History, myth and Polynesian chieftainship: The case of Rotuman kings. In A. Hooper and J. Huntsman (eds), Transformations of Polynesian Culture. Auckland: Polynesian Society, pp. 39-78.

-1986. Cannibal chiefs and the charter for rebellion in Rotuman myth. Pacific Studies 10: 1-27.

- 1996. Speak of the devils: Discourse and belief in spirits in Rotuma. In J.M. Mageo and A. Howard (eds), Spirits in Culture, History, and Mind. New York: Routledge, pp. 121-46.

Howard, Alan and Eric Kjellgren, 1995. Martyrs, progress, and political ambition: Reexamining Rotuma's "religious wars." Journal of Pacific History 29: 131-52.

Howard, Alan and Jan Rensel, 1997. Ritual status and power politics in modern Rotuma. In G.M. White and L. Lindstrom (eds), Chiefs Today: Traditional Pacific Leadership and the Postcolonial State. Stanford, CA: Stanford University Press, pp. 119-49.

2007. Island Legacy: A History of the Rotuman People. Victoria, BC: Trafford Publishing.

Howard, Alan and Robert Scott, 1965. Cultural values and attitudes toward death. Journal of Existentialism 6: 161-74.

Inia, Elizabeth, 2001. Kato 'aga: Rotuman Ceremonies. Suva: Institute of Pacific Studies, University of the South Pacific. 
Ladefoged, Thegn, 1993. Intergroup Aggression and Political Integration in Traditional Rotuman Society. Unpublished PhD dissertation, University of Hawai 'i-Mānoa. Legge, Chris, [1960]. The Cannons of Rotuma. Typescript. Copy in authors' files.

Lesson, René Primavère, 1829. Voyage médical autour du monde exécuté sur la corvette du roi La Coquille, commandée par M. L. I. Duperrey pendant les années 1822, 1823, 1824, and 1825. Two volumes. Paris: Pourat Frères.

Lucatt, Edward, 1851. Rovings in the Pacific, from 1837 to 1849. Two volumes. London: Longman, Brown, Green, and Longmans.

Macgregor, Gordon, 1932 MS. Field notes from Rotuma. Bernice P. Bishop Museum, Honolulu.

Parke, Aubrey, 2001. Seksek 'e Hatana/Strolling on Hatana: Traditions of Rotuma and Its Dependencies. Suva: Institute of Pacific Studies, University of the South Pacific.

Romilly, Hugh, 1893. Letters from the Western Pacific and Mashonaland 1878-1891. London: D. Nutt.

Rotumah Regulations Board, 1884. Regulation No. 1 of 1885.-Regarding Graveyards. Regulations of the Rotumah Regulation Board, Island of Rotumah, Colony of Fiji.

Titifanua, Mesulama and C. Maxwell Churchward, 1995. Tales of a Lonely Island. Suva: Institute of Pacific Studies, University of the South Pacific.

Trouillet, Joseph, [1868]. Histoire de Rotuma. Reel 159 [Microfiche], Pacific Manuscripts Bureau: Canberra and associated libraries.

\begin{abstract}
In this article we look at graves on Rotuma, a volcanic island in the South Pacific, from a cultural and historical perspective. We argue that graves reflect attitudes towards death and ancestors, towards hierarchy and social position; that the location of graves involves spatial conceptions; that grave goods reflect notions of material value; and that grave visitations are indicative of the nature of social relationships between various categories of persons. In addition, a variety of emotions - including love, fear and grief - are embedded and symbolised in the forms, decorations and care of graves. We explore the way social and cultural changes have affected how Rotuman graves are produced and maintained, and the ways in which the graves, in turn, reflect changes that have taken place in Rotuman society.
\end{abstract}

Keywords: Rotuma, graves, death, burial practices

\section{CITATION AND AUTHOR CONTACT DETAILS}

Rensel, ${ }^{1}$ Jan and Alan Howard, 2016. The Culture of Graves on Rotuma. Journal of the Polynesian Society 125 (2): 93-114; DOI: http//dx.doi.org/10.15286/jps.125.2.93-114.

${ }^{1}$ Corresponding author: Center for Pacific Islands Studies, School of Pacific and Asian Studies, 1890 East-West Road, Moore Hall 214, Honolulu, Hawai' $i$, 96822, United States of America. Email: rensel@hawaii.edu 